\title{
A combined computational-experimental study of dynamic responses to olfactory input in a glomerular circuit
}

\author{
Ryan Carey ${ }^{1 *}$, William Erik Sherwood ${ }^{2}$, Matt Wachowiak ${ }^{1,3}$ \\ From Nineteenth Annual Computational Neuroscience Meeting: CNS*2010 \\ San Antonio, TX, USA. 24-30 July 2010
}

Odorant-evoked input to and output from the mammalian olfactory bulb (OB) is temporally dynamic. Olfactory receptor neuron (ORN) inputs are tightly coupled to the respiratory cycle, and inhalation-evoked input bursts occur with durations, rise times, latencies, and strengths (amplitudes) that vary across glomeruli (for the same odorant) and also in individual glomeruli for different odorants [1]. The temporal spread of sensory input following a single inhalation $(\sim 100-300 \mathrm{~ms})$ is comparable to the range of discrimination times for different olfactory tasks [2,3], consistent with these dynamics being important in shaping odor perception. Similarly diverse temporal patterns of activity occur at the level of output from the $\mathrm{OB}$, among mitral cells (MCs), whose firing patterns express strong temporal structure organized around the respiratory cycle and modulated by odorant presentation; significant odor information is carried in these temporal patterns across the $\mathrm{MC}$ population.

We investigate these temporal dynamics using a computational model of the ORN-MC circuit that uses a single-compartment, Hodgkin-Huxley-style MC model [4]. The input to the model MC is taken from recordings of odorant-evoked calcium influx into the presynaptic terminals of ORNs of awake, head-fixed rats engaged in an olfactory discrimination task $[1,5]$. This calcium signal is converted to an excitatory synaptic input for the model $\mathrm{MC}$ having a temporal signature that presumably closely reproduces that of the signal received by real MCs. The response dynamics of the $\mathrm{MC}$ model are strongly shaped by the input signal (Figure 1). We explore how these dynamics vary for
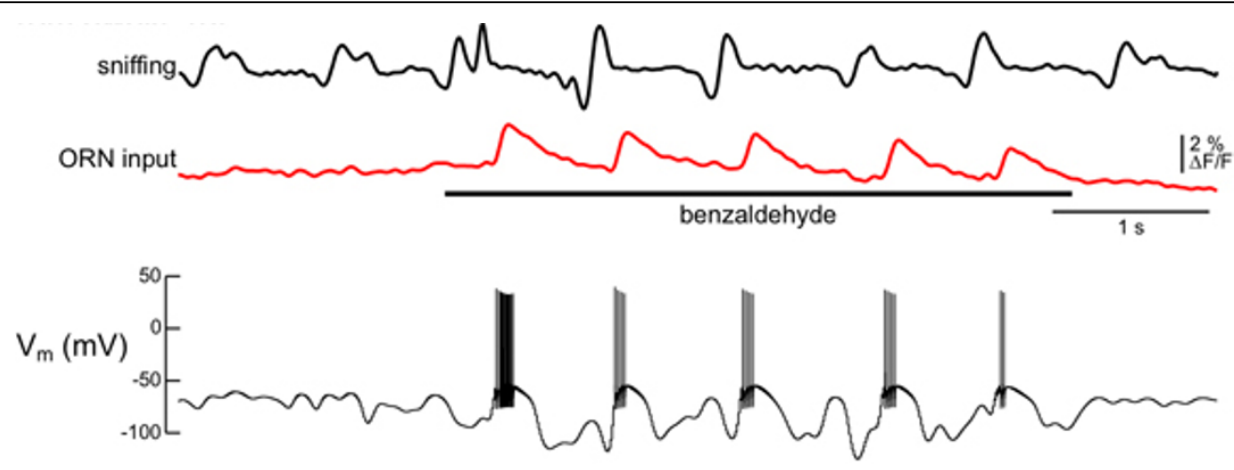

Figure 1 Sniffing and odor-evoked ORN input (top) imaged from an awake rat; ORN input is used to drive a model MC (bottom). Each sniff-evoked burst of ORN input elicits a burst of action potentials in the model MC.

* Correspondence: rcarey@bu.edu

'Department of Biomedical Engineering, Boston University, Boston, MA 02215, USA 
different odorants, synaptic strengths, and intrinsic MC parameters. We also investigate the response of a variant circuit that incorporates a mediating external tufted cell model between the ORN and MC [6].

\section{Author details}

${ }^{1}$ Department of Biomedical Engineering, Boston University, Boston, MA 02215, USA. ${ }^{2}$ Center for BioDynamics, Boston University, Boston, MA 02215,

USA. ${ }^{3}$ Department of Biology, Boston University, Boston, MA 02215, USA.

Published: 20 July 2010

\section{References}

1. Carey RM, Verhagen JV, Wesson DW, Wachowiak M: Temporal Structure of Receptor Neuron Input to the Olfactory Bulb Imaged in Behaving Rats. J. Neurophysiol. 2009, 101:1073-1088.

2. Abraham NM, Spors H, Carleton A, Margrie TW, Kuner T, Schaefer AT: Maintaining accuracy at the expense of speed: stimulus similarity defines odor discrimination time in mice. Neuron 2004, 44:865-876.

3. Wesson DW, Donahou TN, Johnson MO, Wachowiak M: Sniffing behavior of mice during performance in odor-guided tasks. Chemical Senses 2008, 33:581-596.

4. Bathellier B, Lagier S, Faure P, Lledo PM: Circuit properties generating gamma oscillations in a network model of the olfactory bulb. J Neurophysiol 2006, 95:2678-2691.

5. Verhagen JV, Wesson DW, Netoff TI, White JA, Wachowiak M: Sniffing controls an adaptive filter of sensory input to the olfactory bulb. Nat Neurosci 2007, 10:631-639.

6. De Saint Jan D, Hirnet D, Westbrook GL, Chupak S: External Tufted Cells Drive the Output of Olfactory Bulb Glomeruli. J. Neurosci. 2009, 29(7):2043-2052.

doi:10.1186/1471-2202-11-S1-P129

Cite this article as: Carey et al: A combined computationalexperimental study of dynamic responses to olfactory input in a glomerular circuit. BMC Neuroscience 2010 11(Suppl 1):P129.

\section{Submit your next manuscript to BioMed Central} and take full advantage of:

- Convenient online submission

- Thorough peer review

- No space constraints or color figure charges

- Immediate publication on acceptance

- Inclusion in PubMed, CAS, Scopus and Google Scholar

- Research which is freely available for redistribution

Submit your manuscript at www.biomedcentral.com/submit 